\title{
Nest deprivation and mating success in Nile tilapia (Teleostei: Cichlidae)
}

\author{
Francine Z. Mendonça \& Eliane Gonçalves-de-Freitas
}

\begin{abstract}
Laboratório de Comportamento Animal, Departamento de Zoologia e Botânica, Centro de Aqüicultura, Universidade Estadual Paulista. Rua Cristóvão Colombo 2265, 15054-000 São José do Rio Preto, São Paulo, Brasil. E-mail: elianeg@ibilce.unesp.br
\end{abstract}

\begin{abstract}
We tested the effect of nest deprivation on the mating success and sexual selection of dominant Nile tilapia males in two treatments, consisting of two males and three females kept on aquarium with or without nesting substrate (INS: with substrate inside, $\mathrm{N}=9$; NOS: non-substrate inside, $\mathrm{N}=11$ ). Other male traits potentially affecting mating success, such as aggressiveness level, courtship investment, and condition factor were also analyzed. The dominant male's behavior was video-recorded in four 20-min sessions: 1, 4, 7, and 10 days after grouping. Latency to spawn and spawning frequency were similar in INS and NOS groups, showing the same mating success among dominant males on the presence or absence of gravel. Nest investment was the main factor related to female choice in INS groups, but none of the other variables improved mating success in NOS. Although nesting is related to sexual selection in Nile tilapia, gravel substrate deprivation from which they construct a nest does not affect mating success. This finding may explain the reproductive success of the species in a wide range of environments and aquaculture systems.
\end{abstract}

KEY WORDS. Aggressiveness; courtship; reproduction; sexual selection; substrate.

RESUMO. Privação de ninho e sucesso de acasalamento na tilápia-do-Nilo (Teleostei: Cichlidae). Testamos o efeito da privação de ninho sobre o sucesso de acasalamento de machos dominantes em grupos formados por dois machos e três fêmeas, submetidos a dois tratamentos: com e sem substrato (INS: with Substrate Inside, N = 9; NOS: non-substrate inside, $\mathrm{N}=11$ ). Neste último o peixe não podia construir ninho. Outras características dos machos que podem influenciar o sucesso de acasalamento, tais como nível de agressividade, investimento em corte e fator de condição, também foram analisados. $O$ comportamento do macho dominante foi filmado em quatro sessões de 20 minutos: 1, 4, 7 e 10 dias após o agrupamento. A latência para a desova e freqüência de desova foi similar entre os tratamentos, indicando não haver efeito da presença de substrato no sucesso de acasalamento dos machos dominantes. O investimento em ninho foi o principal fator relacionado com a escolha da fêmea no INS, mas nenhum dos fatores influenciou o sucesso de acasalamento no NOS. Embora o ninho seja relacionado com a seleção sexual na tilápia-do-Nilo, a privação de substrato (usado para construir o ninho) não afeta o sucesso de acasalamento. Este resultado pode explicar o sucesso reprodutivo desta espécie em diferentes ambientes e na aquicultura.

PALAVRAS-CHAVE. Agressividade; corte; reprodução; seleção sexual; substrato.

Sexual selection in fishes, as in other animal groups, is related to traits that indicate direct or indirect benefits that enhance the chances for resource access or brood surviving (TURNer 1993, ANDERSSON 1994). In polyginic species, most of the time males invest in mating whereas females invest in good males by assessing their characters and choosing "hot" males, which are the most successful males (Krebs \& Davies 1995, Alcock 2001). In some cases, it has been demonstrated that females actively choose males based on indirect cues, such as nest size or shell qualities in the territory (MCKAYE et al. 1990, MAGNHAGEN 1995, Nelson 1995). Females can also choose males according to direct traits, such as body size (e.g. NeLson 1995, BeECHING et al. 2004), body condition (e.g. Cubillos \& Guderley 2000,
Fessehaye et al. 2006), elongation spines of the first dorsal spine (e.g. Kitamura et al. 2002), dominance (e.g. Gozlan et al. 2003), courtship performance (e.g. CARVALHo et al. 2003; ENGSTRÖM-Öst \& CANDOLIn 2007), or aggressiveness (e.g. Gozlan et al. 2003).

Considering direct traits, female tend to choose aggressive males that dominate and defend good territories for reproduction (GozLan et al. 2003). But, there are some exceptions such as Semotilus atromaculatus (Mitchill, 1818) in which spawning was negatively correlated to aggression levels (Ross 1977). In Bothus podas (Delaroche, 1809) courtship, instead of aggressiveness, was positively correlated to spawning, showing that females prefer mating with males that perform more vigorous courtship (CARvalHo et al. 2003). 
For several cichlid species, nest size is an indirect indicator of male qualities. MACKAYE et al. (1990) studied the Mchenga (= Cyrtocara) eucinostomus (Regan, 1922) and observed a significantly higher frequency of visiting females in bigger nests. Schaedelin \& TABorsky (2006) found that mating craters predict male individual capability and conditions in Cyathopharynx furcifer (Boulenger, 1898). Among Nile tilapia, a lek cichlid species, dominant males defend their territory by digging circular nests, picking up gravel with their mouth and putting it on the edges (Lowe-McConnell 1958, Gonçalves-de-Freitas \& Nishida 1998). Courtship and mating occurs inside the nest (GonçALVEsDE-Freitas \& Nishida 1998). Although nesting is a natural behavior of Nile tilapia, in our laboratory spawning also took place in aquaria and tanks without substrate for nest building. Thus, if the nest acts as a sexual selection character in Nile tilapia as it does for other cichlid species, mating success should decrease at its absence. However, during the reproductive process females may choose attractive males' direct signs that enhance male mating success. In this study we aimed to test the effect of nest deprivation on the mating success in Nile tilapia, and to access the relationship between other characters of dominant males (aggressiveness, courtship frequency, and body condition) and mating success, with and without a nest substrate.

\section{MATERIAL AND METHODS}

\section{Fish rearing}

Nile tilapia, Oreochromis niloticus (Linnaeus, 1758), were obtained from a commercial supplier and maintained first in a hatchery (185 $\mathrm{m}^{3}$ tank) near the laboratory, and then in the laboratory for 15 days before experimentation started. Fishes stayed in $500 \mathrm{l}$ indoor tanks (ca.1 fish/5 l) with non-chlorinated water, temperature $\sim 27^{\circ} \mathrm{C}$ and $12 \mathrm{~L}: 12 \mathrm{D}$ photoperiod (starting at 7:00 am). Biological filters and constant aeration ensured water quality. Commercial pellets for tropical fish were provided twice a day, to satiation.

\section{Experimental design}

The effect of nest deprivation on dominant male's mating success and sexual selection was investigated by removing gravel substrate. Thus, we performed two different treatments consisting of two males and three females kept on aquarium with substrate inside (INS, $\mathrm{N}=9$ ) or Non-substrate inside (NOS, $\mathrm{N}=11$ ). The fish were kept for 10 days in each condition. We used similar-sized fish under the INS and NOS conditions; males in each group were bigger than females, to follow the naturally-occurring pattern (see Tab. I).

In the two male and three female design, hierarchical dominance is established when the dominant male digs the nest and engages in reproduction; the subordinate male usually does not dig nests, stays near the surface and can only reproduces by sneaking (GonÇALVES-De-Freitas \& Nishida 1998). In our research, the dominant male was considered the focal animal because it always engages in reproduction (GonçALVES-DE-Freitas \& Nishida
1998). The dominant male reproductive behavior and the variables related to sexual selection in INS and NOS groups were compared. Procedures are described bellow.

\section{Aquaria, manipulation, and housing conditions}

The $60 \times 60 \times 40 \mathrm{~cm}$ aquaria $(\sim 140 \mathrm{l})$ had three walls covered with an opaque blue plastic to prevent visual contact among neighboring fish; the frontal wall was not covered for video recording. Blue is known to reduce stress (Volpato \& BARRETO 2001) and improve reproduction (Volpato et al. 2004) in Nile tilapia. Water temperature was maintained at $27^{\circ} \mathrm{C}$ in all treatments and the photoperiod was $12 \mathrm{~L}: 12 \mathrm{D}$, starting at 7:00 am. The commercial pellets for tropical fish corresponded to $2 \%$ biomass and were offered twice a day (one hour after the light period had started and one hour before it ended). Continuous aeration and individual biological filters were provided for each aquarium, to keep adequate water conditions. Every four days, $25 \%$ of the aquaria water was removed and replaced by clean water (water was not replaced on the day fish were recorded). The $\mathrm{pH}$ was $\sim 7.5$, and ammonia $\sim 0.25 \mathrm{ppm}$.

Fish manipulations were preceded by anesthesia (benzocaine $16 \mathrm{mg} / \mathrm{ml}$ ). The animals were identified by different cuts on the upper part of the tail fin (see Fernandes \& Volpato 1993, Höglund et al. 2005). Sexing was made by inspection of genital papillae stained with methylene blue so that the female oviduct opening would stand out. At the end of experiments, fish were killed by an overdose of anesthetic and were dissected for gonad inspection and confirmation of sexual maturity. Gonad maturation was assessed by macroscopic inspection, following descriptions for the Nile tilapia provided by BabiKer \& Ibrahim (1979) and by Paiva et al. (1988).

\section{Mating success}

Mating success of dominant fish in both treatments was measured by spawning frequency and latency (days) to spawn. For evaluation of mating success, each group (INS and NOS) was divided into two subgroups after observing the presence or absence of spawning (by female mouthbrooding). The characters analyzed are described as follows.

\section{Behavior}

Behavior was video-recorded for 20 minutes in four observation sessions - 24 hours after grouping and at 72 hourintervals during 10 days. We used such a record to quantify agonistic behavior and courtship.

\section{Aggressiveness level and dominance}

Agonistic behavior was recorded according to the ethogram described for Nile tilapia by Falter (1983), and Alvarenga \& Volpato (1995). Social ranks of males were defined by frequency of attacks (summing all observations) and qualitative cues such as bodies and irises, which are lighter for dominant than for subordinate males (Volpato et al. 1989, Volpato et al. 2003), and also by dominant territory defending on aquarium bottom (Gonçalves-De-Freitas \& Nishida 1998). Domi- 
nant male aggressiveness was inferred from the high intensity of aggression attacks, such as mouth fighting, and lateral fighting and nipping (see Gómez-La Plaza \& Morgan 1993).

\section{Courtship investment}

Courtship frequency was recorded following GONÇALVES-DEFreitas \& NishidA (1998) descriptions. According to those authors, undulation and parallel movements around the female and near aquarium bottom are the main items performing courtship.

\section{Condition factor}

The condition factor $(\mathrm{K})$ was calculated according to Bolger \& ConNelly (1989) and Fessehaye et al. (2006). K = W/SL ${ }^{b}$, where $\mathrm{W}$ was the body weight $(\mathrm{g}) ; \mathrm{SL}$, standard length $(\mathrm{cm})$, and $b=2.07$ is the slope of regression of $\log _{10} W$ on $\log _{10}$ SL, obtained from our fish population. We used the initial weight and Standard Length for K calculations.

\section{Nest investment}

Nest investment was assessed by considering nest digging effort divided by the body weight (Volpato et al. 2004). Aquaria in the INS group were daily inspected for nest occurrence, and nest volume was recorded. The relationship between substrate volume and weight was established to obtain the weight of gravel displaced by the dominant male, dividing it by its body weight. Nest investment (NI) was calculated as $\left.\left.\mathrm{NI}=\left((\pi \cdot h / 3) \cdot\left(\mathrm{R}^{2}+\mathrm{r}^{2}+\mathrm{R} \cdot \mathrm{r}\right)\right) \cdot \mathrm{k}\right) / \mathrm{bw}\right), \mathrm{h}$ being the nest height; $\mathrm{R}$, the major ray; r, the minor ray; k, 2.5 constant nest volume/ gravel weight; and bw, the fish body weight $(\mathrm{g})$. The $\mathrm{R}$ and $\mathrm{r}$ were measured by a compass $40 \mathrm{~cm}$-high, made by wood specially to obtain nest sizes. NI with or without spawning was compared between replicates, and correlated to the frequency of nest visitation by females.

\section{Data analysis}

Shapiro-Wilk's test was used to assess data normality and Fmax for homocedasticity (ZAR 1999). Parametric and non-parametric ( $\alpha$-levels 0.05$)$ analyses were conducted when necessary (Zar 1999, Siegel \& Castellan Jr 2006). Body weight and standard length of males and females were compared by independent Student's t-test. Latency to spawn between INS and NOS treatments was compared by the Mann-Whitney U test. Spawning frequency was transformed into percentage and compared using the Chi-Square test. Male attack and courtship frequencies, condition factor, and nest investment were also compared using the Mann-Whitney U test. Correlation between nest investment and females visiting the nest was testes by Spearman's Coefficient. SAS for Windows was used to data analysis and the a level was set up at 0.05 .

\section{Ethics}

This study is in agreement with the precepts of the Brazilian College for Animal Experimentation (COBEA - www. cobea.org.br) and was approved by the Ethical Committee for Animal Experimentation, Universidade Estadual Paulista, Botucatu, São Paulo (protocol 045-04).

\section{RESULTS}

\section{Social rank and nest building}

INS and NOS groups did not differ in body weight or standard length (Tab. I). The male hierarchical rank was clear for both treatments, dominant males attacking significantly more often than subordinate males. The frequency of attacks by dominant and subordinate males was, respectively median (Q1-Q3) 100.00 (68.00-139.00) and 12.00 (7.00-18.00).80 $\mathrm{min}^{-1}$ for the INS condition; and 133.00 (101.00-193.00) and 6 (4.0013.00).80 $\mathrm{min}^{-1}$ for the NOS condition $(\mathrm{U}=0.00, \mathrm{p}<0.003)$. According to a qualitative visual analysis, all dominant males had lighter bodies and irises than subordinate males, thus confirming the social rank. All dominant males in the INS group built nests and defended them from male and female intruders. NOS dominant males also defended a territory on aquarium bottom by keeping the subordinate close to the water surface.

\section{Mating success}

Spawning occurred only for dominant males and sneaking was not observed. Differences in spawning frequency (INS $\left.=56 \% ; \mathrm{NOS}=45 \% ; \chi^{2}=1.20, \mathrm{p}=0.32\right)$ and spawning latency (median (Q1-Q3); INS = 6.00 (3.00-8.00) days; NOS $=8.00$ (8.0010.00) days; $U=5.00, p=0.12$ ) were not significant.

In the INS group, spawning frequency was significantly higher among males that invested more in nests $(\mathrm{U}=2.00, \mathrm{p}=$ 0.049 , Tab. II); females visiting nests were positively correlated to male nest investment (Fig. 1). No significant association was found between spawning and the other variables tested for the INS and NOS treatments (Tab. II).

\section{DISCUSSION}

The present study indicates that males Nile tilapia that invest more in nest building had the highest mating success. This indicates that nests affect sexual selection in Nile tilapia, but nest deprivation does not prevent spawning nor reduces mating success.

Several studies have reported that mating success in fishes depends on female choice of males' morphological or behavioral traits (Petersson et al. 1999, Kellog et al. 2000, Kuwamura et al. 2000, Kitamura et al. 2002, Fuji et al. 2005, Schaedelin \& TABorsky 2006). In this study, nest investment were related to mating success rather than other behavioral (aggressiveness, courtship investment) or morphological (condition factor) traits in the INS condition, so in disagreement with the most of those cited studies. We found positive correlations between nest investment and frequency of female nest visitation, and association between spawning and nest investment. A similar result was shown by McKaye et al. (1990) for the cichlid species, Mchenga eucinostomus, who build crater-like nests. In this case, more females visit males with higher nests. Thus, these results indicate nest is an important trait to female choice in Nile tilapia.

Sexual selection includes selection of genetic traits on the same sex (intrasexual selection) or on the opposite sex (in- 
Table I. Mean $( \pm S E)$ weight and standard length of males and females from substrate inside-group (INS) and non substrate-group (NOS).

\begin{tabular}{|c|c|c|c|c|c|c|c|c|c|}
\hline & \multicolumn{3}{|c|}{ Dominant males } & \multicolumn{3}{|c|}{ Subordinate males } & \multicolumn{3}{|c|}{ Females } \\
\hline & INS $(n=9)$ & $\operatorname{NOS}(n=11)$ & $\mathrm{P}^{1}$ & INS $(n=9)$ & $\operatorname{NOS}(n=11)$ & $\mathrm{P}^{1}$ & INS (n = 27) & $\operatorname{NOS}(n=33)$ & $\mathrm{p}^{1}$ \\
\hline Weigth (g) & $29.33 \pm 4.41$ & $32.12 \pm 4.84$ & n.s. & $26.58 \pm 4.06$ & $27.80 \pm 4.16$ & n.s. & $22.24 \pm 2.26$ & $24.00 \pm 2.51$ & n.s. \\
\hline Standard length $(\mathrm{cm})$ & $9.35 \pm 0.42$ & $9.48 \pm 0.43$ & n.s. & $9.05 \pm 0.43$ & $9.21 \pm 0.39$ & n.s. & $8.60 \pm 0.33$ & $8.17 \pm 0.30$ & n.s. \\
\hline
\end{tabular}

'Independent Student's t test.

Table II. Median (Q1-Q3) of tested variables for groups related to substrate availability and spawning occurrence.

\begin{tabular}{|c|c|c|c|c|c|c|}
\hline & \multicolumn{3}{|c|}{ Substrate-inside group (INS) } & \multicolumn{3}{|c|}{ Nonsubstrate-inside group (NOS) } \\
\hline & $\begin{array}{c}\text { Spawned replicates } \\
(\mathrm{n}=5)\end{array}$ & $\begin{array}{l}\text { Not spawned replicates } \\
\qquad(\mathrm{n}=4)\end{array}$ & $\mathrm{P}^{3}$ & $\begin{array}{l}\text { Spawned replicates } \\
\qquad(\mathrm{n}=5)\end{array}$ & $\begin{array}{l}\text { Not spawned replicates } \\
\qquad(\mathrm{n}=6)\end{array}$ & $\mathrm{P}^{3}$ \\
\hline Agressiveness level $^{1}$ & $\begin{array}{c}39.00 \\
(37.00-56.00)\end{array}$ & $\begin{array}{c}57.00 \\
(46.0-67.50)\end{array}$ & n.s. & $\begin{array}{c}95.00 \\
(88.0-98.00)\end{array}$ & $\begin{array}{c}84.00 \\
(41.0-100.00)\end{array}$ & n.s. \\
\hline Condition factor & $\begin{array}{c}0.26 \\
(0.25-0.27)\end{array}$ & $\begin{array}{c}0.28 \\
(0.26-0.32)\end{array}$ & n.s. & $\begin{array}{c}0.28 \\
(0.27-0.30)\end{array}$ & $\begin{array}{c}0.27 \\
(0.25-0.34)\end{array}$ & n.s. \\
\hline Courtship investiment ${ }^{1}$ & $\begin{array}{c}18.63 \\
(0.00-42.00)\end{array}$ & $\begin{array}{c}3.50 \\
(1.50-25.0)\end{array}$ & n.s. & $\begin{array}{c}23.00 \\
(14.00-33.00)\end{array}$ & $\begin{array}{c}4.00 \\
(0.00-11.00)\end{array}$ & n.s. \\
\hline Nest investiment ${ }^{2}$ & $\begin{array}{c}84.85 \\
(79.22-105.71)\end{array}$ & $\begin{array}{c}43.95 \\
(28.01-61.10)\end{array}$ & 0.049 & - & - & - \\
\hline
\end{tabular}

${ }^{1}$ Frequency. $80 \mathrm{~min}^{-1} ;{ }^{2}$ Weight of gravel displaced (g)/body weigth $(\mathrm{g}){ }^{3}$ Mann-Whitney test.

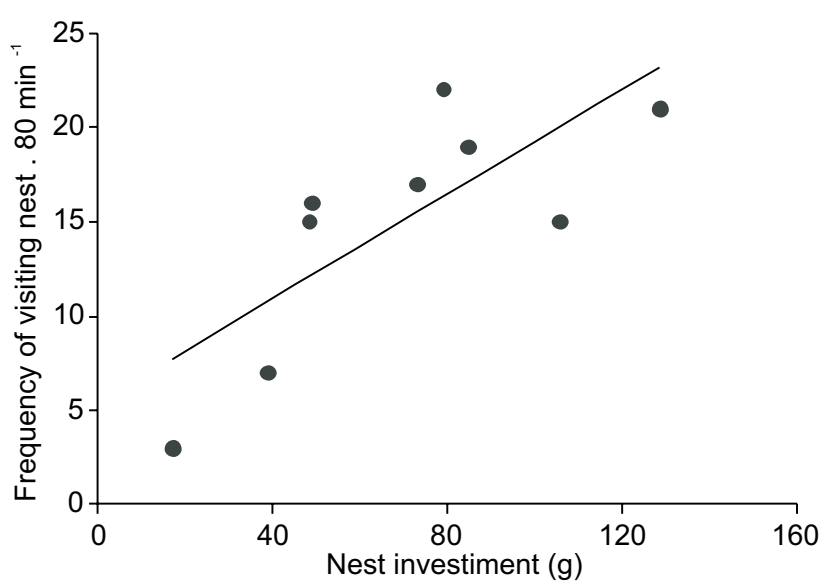

Figure. 1 Spearman correlation between females visiting nests and nest investment by dominant males. $\mathrm{R}=0.73 ; \mathrm{p}=0.03$.

tersexual selection) (ANDERSSON 1994). The intrasexual selection occurs in Nile tilapia with dominant males having priority for spawning (GonÇALVES-DE-Freitas \& Nishida 1998). Thus, it is possible the male competition per se give some genetic information for female. However, the reproductive system of Nile tilapia is lek poliginy, with males building nests near each other (Lowe-McConnell 1958) that supposes female choice among several males. In such condition, it is expected some traits are chosen by females, and this may be the nest.
Although nests affect sexual selection, nest presence was not of primary importance for reproduction in Nile tilapia. In our study, nest absence nor delayed or prevented spawning frequency, which show the enormous behavioral plasticity for reproduction of the species in artificial and poor environment. Moreover, none of the traits tested in the NOS group were associated to mating success, a finding still not corroborated by current theory on polyginic species, which states that females always select some male genetic characteristics (ANDERSSON 1994).

In environments wherein the elements for reproduction or proper stimulus are not found, vacuum behavior is expected (Goodenough et al. 1993). In such a condition, action specific energy continues to build up until it can be contained no more, and then the behavior takes place on its own, without the presence of stimulus (Goodenough et al. 1993). This could be expected in this study, because dominant males defended their territory in aquarium bottom also in absence of a substrate (the proper stimulus). In fact, GALHARDO et al. (2008) found such a behavior in a closed related species, Oreochromis mossambicus (Peters, 1852) in which male display nest building behavior in absence of substrate, thus indicating motivation to dig nest in such condition. However, Nile tilapia did not show vacuum behavior reinforcing the nest is not essential stimulus for reproduction.

Nile tilapia capacity to reproduce in absence of a nest can be explained by two reasons. Firstly, Nile tilapia reproduces in a lek system with symbolic territories and no valuable resources for females (Alcock 2001, Krebs \& Davies 1995, Mckaye 1991). In this case, nests are not elaborated and males defend 
territory on aquaria bottom also when the substrate (and nest) is inexistent. Secondly, females are over-stimulated for reproduction in the presence of males. For example, found the visual stimulus caused by female view of a male can by itself causes to spawning in Nile tilapia, even if the couple is kept separately, with no chemical or physical contact (André Luís da Silva Castro, pers. comm.).

For some cichlid species such as Pterophyllum scalare (Schultze, 1823) and Symphysodon discus Heckel, 1840, spawning frequently occurs in aquaria even in absence of natural elements (pers. observation). However, these species spawn adherent eggs that remain attached to the smooth surface during parental care, and therefore males are not required to dig nests (e.g. Үамамото et al. 1999). Nile tilapia does not spawn adherent eggs, but nest absence does not disturb spawning, probably because eggs are laid in small quantities and in several batches, and are quickly brought into female's mouth.

In summary, nest deprivation did not reduce mating success in Nile tilapia. The nest is a reproductive site and a factor involved in sexual selection, but it is not essential for reproduction. This behavioral plasticity can be one of several reasons for the successful adjustment and survival of this species in different environments.

\section{ACKNOWLEDGEMENTS}

The authors thank Carlos E. Souza, Roselene C.S. Ferreira and Fernanda Pietro for the technical support; André L.S. Castro, Thaís B. Carvalho, and Fabrício B. Teresa for the insightful suggestions and discussions. The research was sponsored by the Conselho Nacional de Desenvolvimento Científico e Tecnológico and by Fundação para o Desenvolvimento da UNESP (proc. DFP 507-05).

\section{LITERATURE CITED}

Alcock, J. 2001. Animal Behavior. Sunderland, Sinauer Associates, XXIII+543p.

Alvarenga, C.M.D. \& G.L. Volpato. 1995. Agonistic profile and metabolism in alevins of the Nile tilapia. Physiology \& Behavior 57 (1): 75-80.

Andersson, M. 1994. Sexual Selection. New Jersey, Princeton University Press, XX+599p.

Babiker, M.M. \& H. Iвrahim. 1979 Studies on the biology of reproduction in the cichlid Tilapia nilotica (L.): gonadal maturation and fecundity. Journal of Fish Biology 14 (5): 437-448.

Beeching, S.C.; C.L. Wack \& G.L. Ruffner. 2004. Female convict cichlids (Archocentrus nigrofasciatus) prefer to consort with same-sized males. Ethology Ecology \& Evolution 16 (3): 209-216.

Bolger, T. \& P.L. Connolly. 1989. The selection of suitable indices for the measurement and analysis of fish condition. Journal of Fish Biology 34: 171-182.
Carvalho, N.; P. Carvalho \& R.S. Santos. 2003. The haremic mating system and mate choice in the wide-eyed flounder, Bothus podas. Environmental Biology of Fishes 66 (3): 249258.

Cubillos, E.R. \& H.E. Guderley. 2000. Analysis of the factors related with mate choice and reproductive success in male three-spined sticklebacks. Journal of Fish Biology 56: 12011216.

Engström-Öst, J. \& U. CANdolin. 2007. Human-induced water turbidity alters selection on sexual displays in sticklebacks. Behavioral Ecology 18 (2):393-398.

FALTER, U. 1983. Les comportaments agonistiques de Sarotherodon niloticus (Pisces, Cichlidae) et al signification évolutive de l'incubation buccale. Bulletin de la Classe des Sciences 69: 566-593

Fernandes, M.O. \& G.L.Volpato. 1993. Heterogeneous growth in the Nile tilapia: Social stress and carbohydrate metabolism. Physiology \& Behavior 54 (2): 319-323.

Fessehaye, Y.; Z. El-bialy; M.A. Resk; R. Crooijmans; H. Bovenhuis \& H. Komen. 2006. Mating systems and male reproductive success in Nile tilapia (Oreochromis niloticus) in breeding hapas: A microsatellite analysis. Aquaculture 256 (1-4):148158.

Fujil, S.; M. Hironaka \& S. Nomakuchi. 2005. Male body size and brooding success under natural conditions in the freshwater Japanese goby, Rhinogobius sp. OR (orange type). Journal of Ethology 23 (2): 127-132.

Galhardo, L.; J. Correia \& R.F. Oliveira. 2008. The effect of substrate availability on behavioural and physiological indicators of welfare in the African cichlid (Oreochromis mossambicus). Animal Welfare 17: 239-254.

Gomez-LaplazA, L.M. \& E. Morgan. 1993. Social isolation, aggression, and dominance in attacks in juvenile Angelfish, Pterophyllum scalare. Aggressive Behavior 19 (3): 213-222.

Gonçalves-de-Freitas, E. \& S.M. Nishida. 1998. Sneaking behavior of the Nile tilapia. Boletim Técnico do CEPTA 11: 71-79.

Goodenough, J.; B. Meguire \& R. Wallau. 1993. Perspectives on Animal Behavior. New York, John Wiley \& Sons, XXVIII+ 762p.

Gozlan, R.E.; C.J. Flower \& A.C. Pinder. 2003. Reproductive success in male sunbleak, a recent invasive fish species in the U.K. Journal of Fish Biology 63 (s1): 131-143.

Höglund, E.; M.J. BaKkeb; O. Øverlic; S. Winberg \& G.E. NilsSon. 2005. Suppression of aggressive behaviour in juvenile Atlantic cod (Gadus morhua) by l-tryptophan supplementation. Aquaculture 249 (1-4): 525-531.

Kellog, K.A.; J.R.J. Stauffer \& K.R. McKaye. 2000. Characteristics that influence male reproductive success on a lek of Lethrinops c.f. parvidens (Teleostei: Cichlidae). Behavioral Ecology and Sociobiology 47 (3): 164-170.

Kitamura, J.; M. Taru \& T. Sunobe. 2002. Female preference of the gobiid fish Eviota bax in relation to elongation of the first dorsal spine in males. Journal of Ethology 20 (2): 133- 
135.

KREBS, J.R. \& N.B. DAVIES. 1995. An introduction to behavioural ecology. Oxford, Blackwell Science, XXII+420p.

Kunamura, T.; K. Karino \& Y. Nakashima. 2000. Male morphological characteristics and mating success in a protogynous coral reef fish, Halichoeres melanurus. Journal of Ethology 18 (1): 17-23.

Lowe-McConNell, R. 1958. Observation on the biology of tilapia nilotica linné in east Africa waters (Pisces: Cichlidae). Revue de Zoologie et Botanique Africaines 57: 129-170.

Magnhagen, C. 1995. Sneaking behaviour and nest defence are affected by predation risk in the common goby. Animal Behaviour 50 (4): 1123-1128.

McKaye, K.R.; S.M. Louda \& J.R. Stauffer. 1990. Bower size and male reproductive success in a cichlid fish lek. The American Naturalist 135 (5): 597-613.

MCKAYE, K.R. 1991. Sexual selection and the evolution of cichlid fishes of lake Malawi, Africa, p. 241-257. In: M.H.A. KeEnleyside (Ed.). Behaviour, ecology and evolution. London, Chapman \& Hall, XXI+378p.

Nelson, M.C. 1995. Male size, spawning pit size and female mate choice in a lekking cichlid fish. Animal Behaviour 50 (6): 1587-1599.

Paiva, P.; J.R. Verani; C.S.R. Mainardes-Pinto \& Y.A. Tabata. 1988. Studies on the growth and reproduction in the cichlid Oreochromis niloticus (Linnaeus, 1757) in a earthern pond. Boletim do Instituto de Pesca 15: 109-114.

Petersson, E.; T. Järvi; H. Olsén; I. Mayer \& M. Hedenskog. 1999. Male-male competition and female choice in brown trout. Animal Behaviour 57 (4): 777-783.

Submitted: 26.V.2008; Accepted: 11.IX.2008.

Editorial responsibility: Kleber del Claro
Schaedelin, F. \& M. TABorsky. 2006. Mating craters of Cyathopharynx furcifer (Cichlidae) are individually specific, extended phenotypes. Animal Behaviour 72 (4): 753-761.

Siegel, S. \& N.J. CASTELLAN JR. 2006. Estatística não paramétrica para ciências do comportamento. Porto Alegre, Artimed, $448 \mathrm{p}$.

Ross, M.R. 1977. Aggression as a social mechanism in the creek chub (Semolitus atromaculatus). Copeia 1977 (2): 393-397.

Turner, G.F. 1993. Teleost mating behaviour, p. 307-326. In: T. J. Pictcher (Ed.). Behaviour of teleost fishes. London, Chapman \& Hall, XX+715p.

Volpato, G.L.; P.M.A. Frioli \& M.P. CARRIERI. 1989. Heterogeneous growth in fishes: some new data in the Nile tilapia Oreochromis niloticus and a general view about the causal mechanism. Boletim de Fisiologia Animal 13: 7-22.

Volpato, G.L. \& R.E. Barreto. 2001. Environmental blue light prevents stress in Nile tilapia. Brazilian Journal of Medical and Biological Research 34 (8): 1041-1045.

Volpato, G.L.; A.C. Luchiari; C.R.A. Duarte; R.E. Barreto \& G.C. RAMANZINI. 2003. Eye color as an indicator of social rank in the fish Nile tilapia. Brazilian Journal of Medical and Biological Research 36 (12): 1659-1663.

Volpato G.L.; C.R.A. Duarte \& A.C. LuChiari. 2004. Environmental color affects Nile tilapia reproduction. Brazilian Journal of Medical and Biological Research 37 (4): 479-483.

Yamamoto, M.E.; S. Chellappa; M.S.R.F. Cacho \& F.A. Huntingford. 1999. Mate guarding in an Amazonian cichlid, Pterophyllum scalare. Journal of Fish Biology 55: 888-891.

ZaR, J.H. 1999. Biostatical analysis. New Jersey, Prentice Hall, XXII+663p. 